\title{
Between Tales, Myths And Mysteries: Beliefs and Superstitions of A Quilombola Community From The Countryside of Northeastern Brazil
}

ERMÍNIA MEDEIROS MACÊDO ( $\square$ erminia.medeiros@hotmail.com )

Universidade Estadual do Piaui https://orcid.org/0000-0002-9102-2904

Roseli Farias de Melo Barros

Universidade Federal do Piaui

Luciano Silva Figueiredo

Universidade Estadual do Piaui

Márcio Luciano Pereira Batista

Universidade Federal do Piaui

Research

Keywords: cosmology, ancestry, superstitions, traditional knowledge, quilombo

Posted Date: June 30th, 2020

DOI: https://doi.org/10.21203/rs.3.rs-36661/v1

License: (c) (i) This work is licensed under a Creative Commons Attribution 4.0 International License.

Read Full License 


\section{Abstract}

Background: Tales, myths, beliefs and superstitions are part of the daily life of traditional communities, which strongly believe in the interference of both natural forces and activities, as well as supernatural ones in their social manifestations. Whether in the imaginary facts or real situations experienced by residents, this set of relationships and symbolisms underlie the cosmology of that social group, through which it is possible to identify traces of the cultural and identity constitution of a people. In quilombola communities, the recurrence of these cultural elements is a common practice. In this perspective, the objective was to recognize the tales, myths, beliefs and superstitions of the Quilombola Custaneira/Tronco community in the state of Piauí, as instruments for reaffirmation and strengthening of traditional knowledge and local culture.

Method: The methodological path was based on the ethnographic approach and the life history through semi-structured interviews with 23 residents, being older or living longer in the locality.

Results: By entering the cosmological universe of the Custaneira/Tronco community and accessing the accounts involving their tales, myths, beliefs and superstitions, we can identify, as in other quilombola communities, the presence of three worlds: the dead, the living and the enchanted.

Conclusions: The conclusive aspects point out that the tales, myths, beliefs and superstitions, like the "Father of the Forest", the visions and the "Mother of Water", greatly influence the social and cultural practices of the community, especially in hunting rituals, in the relationship with animals and with local natural resources. The cosmological arrangement performs functions that organize its social structure and maintain the connection with its ancestors and its traditionality.

\section{Introduction}

Resulting from a process of miscegenation of various ethnic groups, especially European, African and indigenous, cultural diversity is a strong mark of Brazilian society [1]. In every corner of the country, it is possible to find multiple forms of manifestations, cultural expressions and peoples. Among these peoples are the traditional communities, which are characterized, among other elements, by the strong relationship established with their territory, with their culture and with the knowledge of their ancestors [2].

Armed with this knowledge, traditional communities know and appropriate their environment and culture through a "cosmological, sacred, symbolic and spiritual relationship" [3]. Traditional knowledge reveals the universe of experiences and meanings present in the daily life and in the essence of the life of these peoples. This whole set of experiences produces a terrain of feelings and symbologies from which emerge the tales, myths, beliefs and superstitions, which are configured as social phenomena that are present in all peoples, through their various forms and expressions [4]. They are elements that populate the popular imagination, rely on psychological and supernatural forces, reveal constitutive memories of a people's cultural identity and reflect the strong connection with their religiosity, their faith and their ancestors $[5,6]$. In traditional communities, such as quilombolas, the recurrence of tales, myths and 
beliefs is an everyday cultural practice that portrays fictitious or real experiences lived by residents, whose testimonies are perpetuated over the generations.

This field of representations, creations, mores, symbologies and beliefs constitutes the folklore of a community, which is covered by the specificities of the culture of that social group, its worldview, its ancestry, its memories and of the relations established with the environment. Revealing an interconnection between social organization and the natural and supernatural world $[7,8,9]$. These relationships are expressed through "symbolic transpositions" and there are no ontological distinctions between humans and other beings, but rather a strong connection between the different species, whether living or dead humans, plants, animals or spirits, connected by principles of collectivity and sociability $[10,6,11,12,13,14]$.

By establishing a bond between the past and the present, these cultural elements seek to ensure their maintenance and strength among these peoples. However, these elements of the past only make sense when they are able to represent actual realities, that is, when their conservation remains integrated with local systems, as is the case of the important role played by tales and myths in the relationship between man and nature [15].

However, the influence of technologies and new cultures has threatened these traditions, reinforcing the value of studies that propose to validate the importance of these knowledge and beliefs in the lives of these communities. Thus, reaffirming quilombola cosmologies makes it possible to value folk aspects present in the life of these peoples, perpetuating their ancestral bonds and their meanings $[16,17,4]$.

When designed under a sociocultural context, they are established as rules, because they feed on meanings to reaffirm the very existence of that group. Thus, marked by a strong sense of belonging to the group, or even fear of public rebuke and supernatural punishments, traditional communities maintain a relationship of reverence and submission to their beliefs, however cruel and unpleasant they may be, and continue to reproduce exotic mores, eccentric practices and curious superstitions $[18,19,6,20]$.

In Brazil, the Northeast region has the highest record of quilombola communities (61\%), 83 of them in the state of Piaui $[21,22]$. Studies involving the worldview of these peoples can be found throughout Brazil [4]. In the Custaneira/Tronco community, object of this study, culture is one of the main foundations of local practices, greatly influencing the social structure of the community, guiding behaviors and conducts. Considering that these cosmological elements are resignified over the generations, through the creation and re-creation of knowledge, one wonders: What is the meaning of tales, myths, beliefs and superstitions in the life of quilombolas? Can cosmology effectively be a tool that organizes the society of these groups? Finding such answers lead us to consent that the strong bond established by quilombola communities with their traditions and culture makes cosmology assume itself as a determining element within these social organizations.

In this sense, this article proposes to recognize the tales, myths, beliefs and superstitions of the quilombola Custaneira/Tronco community as instruments for reaffirmation and strengthening of 
traditional knowledge and local culture. For this, the myths, tales, beliefs and superstitions with greater influence for that group were identified, as well as the implications that these relationships can bring to the community.

\section{Methods}

Study site

The quilombola Custaneira/Tronco community is located in the semi-arid northeast, within the limits of the municipality of Paquetá/PI, however, its population is also present in the municipality of Santa Cruz do Piauí. Its headquarters is located under geographic coordinates $7^{\circ} 09^{\prime} 49.0^{\prime \prime} \mathrm{S} 41^{\circ} 42^{\prime} 52.0^{\prime \prime} \mathrm{W}$ and its distance to the municipal headquarters of Paquetá is $8 \mathrm{~km}$ and to the municipal headquarters of Santa Cruz is $7 \mathrm{~km}$. It is located in the microregion of Picos, southeast mesoregion Piauiense.

It is about $309 \mathrm{~km}$ from the capital Teresina/PI, and $26 \mathrm{~km}$ from Picos/PI. Due to the geographical proximity and the sociocultural, commercial, family, political and administrative relations established throughout its history, the Custaneira/Tronco community receives influences from the municipalities of Picos, Santa Cruz and Oeiras. In this mesoregion there are large concentrations of afro-descendant population $[23,24]$. From the legal point of law, the community has certification with the official bodies with regard to the recognition of their identity and their quilombola territory.

It currently brings together 167 people and 48 families [23]. Among the main productive activities developed in the locality is subsistence agriculture through the cultivation of small gardens, cassava (Manihot esculenta Crantz), corn (Zea mays L.) and beans (Phaseolus vulgaris L.), or carnaúba (Copernicia prunifera (Mill.) H.E. Moore), receiving government social resources such as bolsa família (similar to Temporary Assistance for Needy Families) and basic grocery packages. During the dry season, some go out in search of different jobs in other states [26].

The climate is Tropical Semiarid Hot, with dry period duration of seven to eight months; the predominant vegetation is arboreal and shrubby caatinga and parts of cerrado (Brazilian savannas) and cerradão (forest in the cerrado) field; the soil is characterized as dystrophic red-yellow latosols, associated with dystrophic litholic soils, dystrophic quartz sands and tropical concretional indiscriminate soils; in relation to water resources, the rivers that cut through the region are Itaim and Guaribas and local streams [24].

All homes have electricity and access to water. The main sources of water come from a well and from natural sources such as the spring water Sucavão, located in the surroundings. In the community there is a Catholic church, an evangelical church, a municipal public school for the operation of the first grades of elementary school, a room where the Culture Point works and also a space for meditation and prayers umbandistas, an open community hall with straw cover, and a recreational club of private property and collective use [23].

Data collection and analysis 
This investigation was constituted by bibliographic/documentary research and field research. In the theoretical research, secondary data were collected through specific literature on the subject, access to the documentary field and database of official institutions. For the field phase, the methodological path was based on the ethnographic approach and life history, extracting oral testimonies, memories, memories of the subjects researched, portrayed through narratives and reports $[27,28,29]$.

The main instruments used to collect these primary data were semi-structured interviews using forms with open and closed questions with the daily field support tools and the recorder [29, 30], in addition to participant and non-participant observation [27, 31, 32]. It was intended, through the life history of the inhabitants, to capture the historical and cultural constitution of that community, where the individual who narrates his trajectory is the main interlocutor, with which a dialogued and cooperative relationship is constituted through interviews, whose objects, inserted in their daily spheres, are reflected in their entirety $[33,34]$. Nonverbal language and comparison with written and imagery sources are elements that should integrate the analysis.

A relationship of trust (rapport) was initially established between the researcher and the community, aiming to ensure greater reliability in the data $[35,36]$. Data were collected between January and September 2019. The universe considered comprised all 48 families in the community. From this total, 23 residents were interviewed, being of greater age group or who have lived longer in the locality who were willing to tell stories of tales, myths, superstitions and beliefs of the community.

The data were collected under the responsibility of a single researcher (E. M. M.), in order to minimize sampling errors. Then, a qualitative analysis of the collected data was performed through the transcription, organization and systematization of the data of the interviews conducted [37]. Among the computational tools used, we highlight the use of Microsoft Excel programs to organize the sociodemographic data collected, NVivo for analysis of interviews and field records and UCINET 6.232 [38].

\section{Results}

The data reveal that $64 \%$ of the residents interviewed are women and $36 \%$ are men. Regarding the age group, $20 \%$ were young (18 to 24 years old), $64 \%$ adults (25 to 59 years) and $16 \%$ elderly (from 60 years). Regarding marital status, $46 \%$ are married and $34 \%$ single. On average, the number of children is between 0 and $2(60 \%)$, followed by the range between 3 and 6 children (36\%).

Regarding education level, $22 \%$ are not educated. Among the others, $20 \%$ completed high school, $30 \%$ had elementary school I ( 1 st to 4 th grade) or II (5th to 9 th grade) incomplete, $14 \%$ are literate, $6 \%$ attend elementary school I or II, $4 \%$ have incomplete high school and $4 \%$ have completed higher education. Regarding the profession, $54 \%$ of the residents are rural workers, with an income of less than 1 minimum wage (60\%). The main origin of income is production in the field (74\%). Regarding the time they live in the community, 58\% have more than 40 years of housing. 
The sociodemographic aspects of the Custaneira and Tronco communities show data common to the reality of many quilombolas, such as the low level of education as observed in the studies by [39, 40,41]. The same situation occurs with regard to the main occupation as a rural worker and income, which does not exceed a minimum wage. Low income is part of the context of quilombola communities in Piauí and Brazil, according to the researches of $[42,43,44,45]$.

With regard to cosmological aspects, the Custaneira/Tronco community is recognized by a cultural dynamic strongly linked to beliefs, tales, myths and superstitions, through which symbolisms are revealed to determine the local way of life.

\section{Mysteries and hunting in Xico Banana}

Xico Banana is an area situated in the forest within the territory of the community much used by residents to hunt. The place is transmuted from the mysteries that surround it. "There is a place here on the plateau they call the Xico Banana or Xite Banana. Never a hunter went hunting there at night so he would not get lost. Born and raised here, every hunter during the night, who goes hunting there at night if "area", gets areado. And then there were many of them who saw a stir in the slap, see that fuss and ends... the late Joel here from Tronco he got lost up there and so it was what they call to be areado, it was such a reaction that the person was on top of the plateau, went down to the baixão and went there arriving in Santa Cruz and only went to desarear there in Curralinhos (I 1, 42 years old)."

It is not known to explain what happens, but all the stories told, especially those related to hunting, report the presence of magical and supernatural forces influencing their actions on the spot. There is night, hunt there at night... I, for example, another boy married to a cousin of mine here hunting with dogs, is areado. "It is something related to the place, it is a myth of the place that makes it hard for a hunter that goes up in the Xito Banana to escape (I 1, 42 years old)."

According to [23] "for many hunters or former hunters, on some days of the week or in some certain situations the best thing to do is to retire home or not leave home for this type of activity". "There are days when the visagens are many, it is in the dead hours of the night, people see thing. The thing when it is like this can come home that nothing comes out and happy when the person has the determination to leave and is not vareado, wrong in the plate (I-5, 56 years old)."

The hunting stories in the community also bring accounts of the influence of supernatural beings and of magic works done by people in the community to hinder the hunting of others. "When hunting is during the day, dogs do not go, but people also take some things for the rifle. When you're not hitting the shots says the rifle can be endeada, then they wash, pass the wax of a bee that has the cupira in the pipe outside to desendear the shotgun because it is said that the shotgun endea. There are people who endea, also endea the dogs, as if it is areado, he cannot do anything, in the same way the gun that does not hit shot. When the hunter realizes he is just missing a shot, it is because the gun is endeada. Now this question of endear are evil people who endea, endea the things, do on purpose, does the mandinga. The 
person goes hunting there, the person in the house heard and does not want him to take anything, then endea $(\mathrm{I}-3,72$ years old)."

"Such enchanted entities can determine the behavior of hunting dogs, the behavior of the hunt and the orientation or disorientation of hunters during the hunting venture" [23]. "The dog is howling, howling areado. Then the person says: look, the dog is endeado. Then you have to pass the garlic on the dog forming a cross, pass it on his nose, and turn it there three times then it works. Then he takes the shovel or the hoe, which the hunter always takes the hoe, that is short, then takes the machete and is beating on the side and another of the hoe, beating up the hoe and shovel, it even makes that high pitch noise, then they stop for a bit and then is that the dog begins to nose again, because he loses his nose there if hunting was walking, because when the hunter hiss is because the hunting is walking, then the hunter calls (I-1, 42 years old)."

\section{Voices crying at Oi D’ Agua}

The Olho D'água Danta was named Danta because the older residents said that there was a tapir. It always has been a source of water widely used by residents of the community, but what draws attention to the place are the reports of the constant crying of a child, awakening in the residents' fear of the place, as if the spirit of that child was still present. "In the Oi D'agua we hear voice as if it were a crying boy. Here in Oi D' água Danta there was a stone that cried like a child they had to baptize this stone. I do not know who baptized the stone, but heard the child cry. No one knows whose child the child was and no one knows if it was a child or a mother who aborted a child there because it is very old the history from here (I- 2, 60 years old)."

\section{The Giant Scissors of Sucavão}

Sucavão is an important local water spring that is situated very close to the community. It is a place much visited by people from the region for baths, however many residents believe that the place is macabre and dangerous. "Says there is scissors in the Sucavão. The older ones say that it is a large scissors that said it opens and closes, as if it were a stone, in the shape of a stone and that it is not recommended to enter there. A lot of people are afraid to bathe in there because they're afraid to get in the moment that this scissor closes (I-11, 40 years old)."

The reports converge, usually, to stories of hauntings and deaths and report the presence of mythical entities such as sucur. Moreover, Sucavão recalls sad memories of the slavery of its ancestors. "What happened there is that it is said that the colonels here from various slave quarter such as Buritizinho, the slave quarters Arabutão, the one there of Canabrava, from Irajá, adopted a kind of punishment that was to tie the blacks and shred, pass the razor and shredded, put salt and pepper. The blacks ran and jumped into the Sucavão to see if it softened, tried to take away the burning and the pain. They were coming right in the last few days, jumping in there and it is said that there died many blacks. Therefore, there is all this energy that prowls there and the older ones relate this. The water spring of Sucavão was thus towards the downward course, including in 2003, 2004, the black flogging trunk was still standing (I-1, 42 years old)." 
For all this, in almost all families in the community, fathers and mothers recommend not visiting and in some cases even forbid their children from going to Sucavão. "I grew up afraid of Sucavão because it is said that there is a sucuri that catches people... before was said that it tied an ox once, and it is said that it ate this ox. I bathe there a few times but I am afraid of this sucuri. Today we think there is no more in some waters like that over there... I know they tell you a lot that there was sucuri (I-1, 42 years old)."

The Sucavão is very deep, is told the person who arrives in the background because many people have died (I-5, 56 years old)." "It is common for another person to die drowned there... and you're told what you can get. Mom does not like us going at all (I-1, 42 years old).

\section{Voices, steps and "visagens" in the senzala and Casa Grande of Buritizinho}

The Buritizinho slave quarter was part of the Buritizinho Farm, located within the territory of the community. For decades, it was the workplace of many residents. The physical space does not exist, but the memory of the residents records many stories about the place, especially the reports of voices and the fat on the walls of the rooms of the salve quarters.

It is believed that the voices, the weird noises and the fat were from the blacks who died there. "There in the Buritizinho slave quarter it is said that there is a room there that they heard voices, the dark room, they called it that because there was no window, it was a hole. It is said that people heard a voice and also said that in this room mined on the walls as if it were a fat, an oil that they said was from the blacks who died there (l-1, 42 years old). At night there in the slave quarters also assuntava as if the ox cart stopped, then the person called the names of the ox: .calm down Pintor. They tell that it was like a penitence that the spirits keep doing ( $(-3,72$ years old)."

Still on the Buritizinho Farm, many residents narrate stories from the past that suggest the presence of the spirits of people who have died and who have remained there to haunt the living. "In the time, I lived in the house of the slave quarters, at night there were some movements. My wife was haunted and I said oxente be quiet that it is not an ounce to eat us. That is what we saw, when we went after it there was nothing (I-3, 72 years old). Mom did not stay alone in the Casa Grande at all, many people ran in fear of these things that appeared there ( $(-1,42$ years old). Everyone who lived there heard this fuss, to stay one person to be there alone, vixe, a woman to sleep in the Casa Grande alone or a boy, a man alone was very difficult. The fuss was big (I-3, 72 years old)."

\section{The "curse" of the Tronco}

The Tronco community, although it is very close to the Custaneira community, forming in practice a single community, brings in its history reports that attribute to the place curses and fears. The residents say that when the first residents of the region went on pilgrimage in the city of Juazeiro do Norte, Ceará, Father Cicero made a prophecy that one day the Tronco will sink and kill the people who are passing by now. "Since I was a child, I hear history and then I am afraid to this day, so we imagine to this day. My Padim Ciço said that whoever went to Juazeiro was not supposed to pass in the Tronco, that the Tronco will 
sink. They say there is a wreck ( $1-13,55$ years old). In the old days, when we went there was afraid, when we were going to give a message there in Tronco, first, the fear was to get there and the Trunk sink head in and us and everything (I-1, 42 years)."

"However, the tale itself was on the way to Juazeiro ( $1-7,71$ years)." "The thing there is so much that the people put up party on Holy Wednesday (I-5, 56 years old)." The recommendation, therefore, was to avoid passing through the site. Although many years have passed, to this day residents of neighboring communities believe that the place has a dense and negative energy.

\section{Haunting on the Pedra Lisa}

Pedra Lisa is a place that is close to the border between the Communities Custaneira and Tronco and that has already recorded many testimonies of hauntings and sightings by residents. "My father said he went to get a saddle there in Canabrava, He said that when it was about six o'clock said I'm leavin, but the older ones had this story that you should not do anything at the time of six and twelve. When he was arriving at the Pedra Lisa he heard that cry behind like someone wanted to talk to him, and he said he started to shiver. He said he was going, he was going, he was going, he was going and then it was over. (I- 5 , 56 years old). It is hard for a person to go there after six hours and not see haunting. (I- 5, 56 years old). It was a fuss on this Pedra Lisa (I-1, 42 years old)."

\section{Father of the Forest}

Father of the Forest is the entity that protects the forests and all the stories that accompany it are located in the plate, an extensive area located in the middle of the forest of the community, without any signs, where it is necessary to go accompanied by older residents in order not to get lost. However, even these residents who claim to be knowledgeable about the area have already been lost, reinforcing the belief in the influence of supernatural entities in that place and in the need to obtain their permission and make offerings to enter their space. "Here the spirit that protects the forests is the Father of the Forest or the Hunter ( $1-3,72$ years old). It was never safely talked about his image, but when he was hissing here, we already know that the Hunter is calling, and then we can go hunting that has hunting. We hear the hissing all the time, at all times of the year, always at night, after seven hours, having already closed the night. It is like someone hissing, and then we listened and went hunting. To enter the forest, the experienced hunters always did rituals, but these people today do not know these things anymore, but the older did, asked for permission, many of them put tobacco in the forest, carried garlic, always. We take, we, at least me and the people of my time do not go to the woods without taking the garlic clove, a protection that is even for us and also for the dogs that always accompany in the hunts at night, because when the dog is a little confused in the forest, then we rub the garlic and pass on his nose (I-5, 56 years old). There are people around here who call the Father of the Forest of Caipora. That is why they say it's Caipora's, because he smokes. He is the one we put the tobacco for. There is myth of cases that they testify that if you forget the offering you are punished (1 1, 42 years old)."

When the man insists on entering without authorization, he cannot do anything because he gets lost and gets areado, as the residents tell. "In this myth they count, one boy was beaten up, a lot, stood for himself, 
and the other person right there seeing the other feel the beats. You only see the person cursing and beating is happening. The late Manoel Canoa put tobacco every time he went to the Pedra Lisa, then one day he forgot. He said he was beaten up so much that it was pity, never to forget. Sometimes he beats the dog too, because something can happen that did not work out with the dog, and even the dog is beaten up ( $(-5,56$ years old)."

\section{The Mother of Water}

Just as there is a belief in the entity of the Father of the Forest to protect forests and woods, the residents also believe in the presence of enchanted beings who protect waters. In the case of the Custaneira/Tronco community, the black snake represents this being. "The waters have their sciences, they all do. There are times we see weird things in the water. For example, we do not usually use a bowl because they say that it is forbidden to take water from the fountain with the coité. Our elders did not give permission because we cannot take water from the source with coité and carry to another corner (I 1, 42 years old)."

The stories told by the residents demonstrate a deep relationship of respect and sacredness with this animal, which, when not respected, imposes punishments on those who do not obey it. "The black snake is the mother of water. We do not usually kill black snakes at all. If you kill her, the waters will dry up. We do not kill black snakes at all, because besides being the water mother it is said that she also eats the other snakes. There is some of them that are big, but there is the black snake with a thin tail, boy, she made us run a lot, she ran after us anyway. I was exhausted up there at uncle Inácio's house, from the water springs that had there, me and the girls of Uncle Inácio, Cumade Marilene, we were going to get donkey, these things, the black snake has already appeared behind us, and you had to see. There were people who killed the black snake and the spring of water dried up. Saquinho's water spring dried up. Whoever killed the black snakes there near the water's spring dried everything (I -13, 55 years old)."

When we go to make use of water, we do not take anything like in the woods, only in the time of the entities that we go there at the source and put the offerings, as on Oxum Day that we go to the fountain and put a food, and also on The Day of Yemanjá (I-1, 42 years).

\section{Discussions}

By entering the cosmological universe of the Custaneira/Tronco community and accessing the accounts involving their tales, myths, beliefs and superstitions, we can identify, as in other quilombola communities, the presence of three worlds: the dead, the living and the enchanted, among which a network of meanings, spells and representations is intersected and allows us to make reflections about the relationship between man/nature/culture as can be seen in the stories involving voices in aquatic environments, black snake, sucuri and scissors in the water springs Danta and Sucavão.

Water is a fundamental element for the maintenance of life and "finds frank acceptance in the imaginary of all peoples" [46]. Much more than a material resource, its symbolic dimension stands out. According to 
[47], "europeans, Africans and indigenous people wrote and mixed their beliefs and myths", thus enabling a breadth of mythological manifestations and worldviews on the aquatic surfaces of Brazil [48, 49]. An example of this can be found in the studies of [50], which reports tales and superstitions with serpents and snakes in the waters of the Mata Cavalo community, Mato Grosso. In another research, [47] portrays the belief in supernatural beings and water spirits in quilombola communities located in the Vale do Ribeira, between the states of São Paulo and Paraná, as part of the historical, cultural and symbolic constitution of those groups.

It is perceived that all these stories are intertwined in mysteries and "senses of ethnic belonging" [51, 52]. that converge in convictions about the existence of supernatural forces and influences in these places, driving the residents of the community to act with a certain fear, as observed in the various narratives of Sucavão. This fear brings consequently less visitation and exploitation, inducing protection, and, leading us to consent that beliefs in imaginary beings often function as instruments for the conservation of local resources. This dynamic in which the cosmology of traditional communities is constituted consists of relationships established between cultural manifestations and local ecosystems, through which residents guarantee their survival and the spiritual entities act as guardians $[53,54,55,9]$.

In relation to the reports of the Father of the Forest, Hunter or Caipora, it is perceived that in the Custaneira/Tronco community, adults and older people are the ones who most respect the strength of this protective spirit of the forest. That there are many stories told by residents about the presence and influence of enchanted entities that govern nature, forests, hunting and hunters, influencing the behavior of dogs that accompany the hunts, and hunters [23]. The permission granted by the Father of the Forest is usually revealed through signs such as the hissing and the tobacco that is offered to this entity. "Asking for permission is a way to seek harmony with the beings of the universe and to live well in the community" [56].

In fishing communities in Brazil, Caipora also exists and is known as a mythical being that makes people get lost in the mangrove if their orders are not fulfilled [53]. In the Northern region, specifically on Marajó Island, this entity is named Curupira, but its figure represents the feminine, called "Mother of Water" [56]. These distinct and, at the same time, similar formats, demonstrate that imaginary beings are present in many traditional communities in Brazil, sometimes given different names, but fulfill the same protectionist role to natural resources.

This symbolic field that permeates the daily practices in the Custaneira/Tronco community, such as hunting, is covered by religious representations, especially of umbanda, when the protection of Yemanjá and other protective spirits of nature is invoked. This dynamic demonstrates an almost sacred relationship with nature, where respect is instituted through obedience to the signs they listen to and rituals they do before entering the forest to hunt, or even when they need to "destocar" the area, put fire for planting. For [23], this intersection of religions can also reveal the presence of other cosmological elements in the territory of the community, as it aggregates "different degrees, of religiosity, of indigenous, 
Afro-Brazilian and Catholic symbols and meanings; making the enchanted central elements in the cosmologies" of these peoples $[57,58,56]$.

It is observed that these religious rituals are common to other quilombola and indigenous communities where the belief in spiritual and imaginary beings that protect the woods, waters and forests is very solid, however, each community dresses and expresses its perspectives according to its values, reaffirming the prerogative that "the meaning of a sign is not intrinsic, but a function of the discourse in which it is inserted and its structure" [33].

Most of the tales, myths, superstitions and beliefs of the Custaneira/Tronco community revolve around travels, voices, hauntings and strange noises and, usually, refers to signs of dead people or animals, generating fear among residents. These hauntings are usually the same and are common throughout Brazil. It is as if spiritual beings appeared through voices, groans, and footsteps [1]. Similar hauntings were reported in the old "casas-grandes" in Rio de Janeiro and São Paulo, in the Paraíba valley and in Recife. These manifestations generate fear, but also reactions of respect, causing residents to distance themselves from places considered cursed. Religiosity is also present through prayers, used to ward off any evil.

Myths, tales, beliefs and superstitions can hardly be explained from the truth of logic and science, which does not imply demerit in the value they bring [59]. On the contrary, for traditional peoples, "beliefs and practices do not lack any consistency, because, their knowledge of the outside world is sufficient to guide them in most of their arduous activities" [27].

The understanding of these multiple dynamics of symbologies, magic and cultural representations reveals a set of values and beliefs that is present in the daily practices of quilombolas and set their way of acting through the validation of patterns of behaviors that are established in the social imaginary, integrate into the affective universe, represent their traditions and moral references $[3,51,60]$, and thus ensure permanence and continuity throughout the generations.

\section{Conclusions}

By entering the cosmological context of the Custaneira/Tronco community, it is possible to make some considerations. The first refers to the multiplicity of beliefs, tales, superstitions and myths present in their daily lives, which could not be included in this article in its entirety. The second observation is about the technical/scientific view, which is often limited to portray often inexplicable and incomprehensible phenomena. Another aspect showed that the research focused on older residents, demonstrating that older people are more interested in transmitting their beliefs, their knowledge and their stories.

Myths, tales, superstitions and beliefs bring in essence a unique truth for those who live it, which is translated through the symbology that such truth represents in their lives, and which cannot be explained in its entirety through logical reasoning. In this web of beliefs, supernatural forces merge with natural ones, and reveal mysteries, secrets and mystical relationships, mixing fiction with reality. 
In the daily life of traditional and quilombola communities, as well as in the Custaneira/Tronco community, the cosmological arrangement performs functions that organize its social structure and maintain the connection with its ancestors and its traditionality. Whether in the activities of hunting, fishing, dancing, feeding, planting, harvesting, cosmology is established as an instrument that both gives meaning to its own existence and brings solidity to the quilombola identity of that group.

Finally, the plurality of symbolisms manifested in the cosmology of the Custaneira/Tronco community made it possible to know its particular forms of interpretation of the world and phenomena from its symbolic representations and social and environmental relations established between the various beings, man, nature and its territory, denoting a much more extensive, rich and profound cosmological tessitura that could not be exhausted in this article.

\section{Declarations}

\section{Ethics approval and consent to participate}

The present study was approved by the Ethics Committee of the State University of Piauí in the Campus (assent number: 2.627.953) and registered in the National System for the Management of Genetic Heritage and Associated Traditional Knowledge -SISGEN (assent process: A68AC38).

\section{Consent for publication}

The participants of this study were informed about the study's objectives and the eventual publication of the information gathered, and they were assured that the informants' identities would remain undisclosed, according to Resolution No. 466/12 of the National Health Council (CNS).

\section{Availability of data and materials}

The datasets used and/or analyzed during the current study are available from the corresponding author on reasonable request.

\section{Funding}

No funding was received.

\section{Competing interests}

The authors declare that they have no competing interests.

\section{Authors' Contributions}


EMM carried out the field survey and collected the data. EMM and LSF performed the literature review. EMM interpreted the data and wrote the manuscript. LSF, RFMB and MLPB critically reviewed and rewrote sections of manuscript. All authors read and approved the final manuscript.

\section{Acknowledgements}

We thank all residents of the Quilombola Custaneira/Tronco community who took part in this study.

\section{Author details}

${ }^{1}$ Development and Environment Graduate Program, Federal University of Piauí (UFPI), Universitária, Teresina, Piauí, 64049-550, Brazil. ${ }^{2}$ Department of Biology, UFPI, Teresina, Brazil. ${ }^{3}$ Nature Science Center, State University of Piauí (UESPI), 25 Highway BR230, Picos, Piauí, 64600-000, Brazil

\section{References}

1. Freyre G. Casa-Grande e Senzala: formação da família brasileira sob o regime da economia patriarcal. São Paulo: Global; 2006.

2. Viveiros de Castro E. Economic development, anthropomorphism, and the principle of reasonable sufficiency. In: Gagliardi P, Reijnen AM, Valentini P. Protecting nature, saving creation. Ecological conflicts, religious passions, and political quandaries. 1ed. New York: Palgrave Macmillan; 2013. pp. 161-80.

3. Diegues AC, Arruda RSV. Saberes tradicionais e biodiversidade no Brasil. Brasília: Ministério do Meio Ambiente; 2001.

4. Cascudo LC. Literatura Oral no Brasil.. São. Paulo: Global Editora; 2009.

5. Cunha LHO. Significado múltiplo das águas. In: Diegues AC, editor. A imagem das águas. São Paulo: Hucitec; 2000. pp. 15-26.

6. Malinowski B. Crime e costume na sociedade selvagem. Brasília: Editora Universidade de Brasília; 2003.

7. I Encontro Internacional: Governança da Água [evento na internet]. 2007 out 29 - 01; São Paulo, Brasil [acesso em 20 jan 2017]

Diegues AC. Água e cultura nas populações tradicionais brasileiras. 2007. In: I Encontro Internacional: Governança da Água [evento na internet]. 2007 out 29 - 01; São Paulo, Brasil [acesso em 20 jan 2017]. Disponível em: < http://nupaub.fflch.usp.br/sites/nupaub.fflch.usp.br/files/color/simbolagua.pdf.

8. Diegues AC. The role of ethnoscience in the build-up of ethnoconservation as a new approach to nature conservation in the tropics. Rev d'ethnoécologie. 2014. https://doi.org/10.4000/ethnoecologie.1956. 
9. Silva AB, Lopes JB, Figueiredo LS, Barros RFM de, Souto WMS, Alencar NL, Lopes CGR. Water spirits within the fishers' worldview: implications for fishing management in Northeast Brazil. J Ethnobiol Ethnomed. 2019. https://doi.org/10.1186/s13002-019-0350-z.

10. Malinowski B. Magia, ciência e religião. Lisboa: Edições 70; 1988.

11. Viveiros de Castro E. Araweté - povo do Ipixunas. Rio de Janeiro: Artes Gráficas LDA Ed; 1986.

12. Viveiros de Castro EB. A Inconstância da Alma Selvagem e Outros Ensaios de Antropologia. São Paulo: Cosac \& Naify; 2002.

13. Descola P. Ecologia e cosmologia. In: Castro E, Florence P. Faces do trópico úmido: conceitos e questões sobre Desenvolvimento e Meio Ambiente. Belém: Edit. Cejup; 1997. pp. 243-61.

14. Fausto C. Banquete de gente: comensalidade e canibalismo na Amazônia. Mana. 2002. https://doi.org/10.1590/S0104-93132002000200001.

15. Freitas AC, Cardoso IS, João MCA, Kriegler N, Pinheiro MAA. Lendas, misticismo e crendices populares sobre manguezais. In: Pinheiro MAA, Talamoni ACB. Educação Ambiental sobre Manguezais. São Vicente: UNESP, Instituto de Biociências, Campus do Litoral Paulista; 2018. pp. 144-65.

16. Karlberg LGL. Rezas, benzeduras, superstições em Sena Madureira, Acre. Revista da Academia Brasileira de Filologia. 2012;21:127-42.

17. Dias ACR, Reis SWC. A ecologia dos sentidos: percepções a partir dos saberes dos povos e comunidades tradicionais. In: Anais do II Congresso Nacional de Educação; 2015 out 14-17; Campina Grande, PB. Campina Grande: Editora Realize; 2015. p. 1-12.

18. Diegues AC. A imagem das águas. São Paulo: Hucitec; 2000.

19. Little P. Territórios sociais e povos tradicionais no Brasil: por uma antropologia da territorialidade. Anuário Antropológico/Tempo Brasileiro. 2002;28(1):251-90.

20. Toledo VC, Barrera-Bassols N. A etnoecologia: uma ciência pós-normal que estuda as sabedorias tradicionais. Desenvolvimento e Meio Ambiente. 2009.

DOI:http://dx.doi.org/10.5380/dma.v20i0.14519.

21. Brasil. Guia de Políticas Públicas para Comunidades Quilombolas: Programa Brasil Quilombola. Brasília: Secretaria de Políticas de Promoção da Igualdade Racial; 2013.

22. FCP - Fundação Cultural Palmares

[web page]

Acessed 29 de Oct 2019.

FCP - Fundação Cultural Palmares. 2019. [web page]. URL. http://www.palmares.gov.br/. Acessed 29 de Oct 2019.

23. Sousa AJ. Etnicidade e territorialidade na comunidade quilombola Custaneira/Tronco, município de Paquetá - PI, Brasil. Teresina. Dissertação [Mestrado em Sociologia] - Universidade Federal do Piauí; 2015.

24. IBGE - Instituto Brasileiro de Geografia e Estatística 
[web page]

Acessed 02 Nov 2019.

IBGE - Instituto Brasileiro de Geografia e Estatística. 2019. [web page]. URL: http:// https://cidades.ibge.gov.br/brasil/pi/paqueta/panorama. Acessed 02 Nov 2019.

25. Figueredo ES. Custaneira/Tronco community location [map]. Teresina: UFPl; 2020.

26. Aragão JA. Acesso de saúde na atenção básica prestada aos quilombolas, Piauí. Porto Alegre. Tese [Doutorado em Gerontologia Biomédica] - Pontifícia Universidade Católica do Rio Grande do Sul; 2014.

27. Malinowski B. Argonautas do pacífico ocidental. São Paulo: Abril Cultural; 1922.

28. Spindola T, Santos SR. Trabalhando com a história de vida: percalços de uma pesquisa (dora?) Revista Escola Enfermagem. 2003. https://doi.org/10.1590/S0080-62342003000200014

29. Flick U. Desenho da pesquisa qualitativa (Coleção Pesquisa Qualitativa). Porto Alegre: Bookman/Artmed; 2009.

30. Oliveira MM. Como fazer pesquisa qualitativa. Petropólis: Vozes; 2007.

31. Alvesson M, Sköldberg K. Reflexive methodology: new vistas for qualitative research. 3rd ed. Thousand Oaks: SAGE Publications Ltd; 2017. p. 465.

32. Fetterman D. Ethnography. In: Bickman L, Rog DJ, editors. The SAGE Hand Appl Soc Res Methods. Thousand Oaks: SAGE Publications Ltd; 2009. pp. 543-88.

33. Cunha MC. Cultura com aspas e outros ensaios. São Paulo: Cosac \& Naify; 2009.

34. Silva PV, Barros DD. Método história oral de vida: contribuições para a pesquisa qualitativa em terapia ocupacional. Revista Terapia Ocupacional. 2010. DOl:https://doi.org/10.11606/issn.22386149.v21i1p68-73.

35. Bernard RH. Research methods in cultural anthropology. SAGE Publications; 1989.

36. Sieber JE, Tolich MB. Planning ethically responsible research. 2nd ed. Thousand Oaks: SAGE Publications Ltd; 2012.

37. Bardin L. Análise de conteúdo. São Paulo: Edições; 2011.

38. Borgatti SP, Everett MG, Freeeman LC. Ucinet for Windows: Software for Social Network Analysis. Harvard: Analytic Technologies; 2002.

39. Aguiar LGG, Barros, RFM. Plantas medicinais cultivadas em quintais de comunidades rurais no domínio do cerrado piauiense (Município de Demerval Lobão, Piauí, Brasil).. Revista Brasileira de Plantas Medicinais. 2012. https://doi.org/10.1590/S1516-05722012000300001

40. Terceiro A, Silva JJS, Correia MF. (2013). Caracterização da sociedade, economia e meio ambiente costeiro atuante à exploração dos manguezais no estado do Maranhão. Revista de Administração e Negócios da Amazônia. 2013; 5 (3): 94-111.

41. Alves RJM, Pontes NA, Gutjahr ALN. Caracterização socioeconômica de comunidades rurais amazônicas do estado do Pará, Brasil. Observatório de la economia latino-americana. 2015. 
42. Brasil. Alimento: direito sagrado. Pesquisa Socioeconômica e Cultural de Povos e Comunidades Tradicionais de Terreiros. Brasília: Ministério do Desenvolvimento Social e Combate à Fome; 2011.

43. Baptista NQ, Campos CH. A convivência com o semiárido e suas potencialidades. In: Conti IL, Schroeder EO. Convivência com o semiárido brasileiro: autonomia e protagonismo social. Brasília: Editora IABS; 2013. pp. 51-8.

44. Superti E, Silva GV. Comunidades quilombolas na Amazônia:construção histórico-geográfica, características socioeconômicas e patrimônio cultural no estado do Amapá. Revista FrancoBrasileira de Geografia. 2015. https://doi.org/10.4000/confins.10021.

45. Batista WFM., Santos, KPP, Figueiredo, LS, Barros RFM. Sociedade e Cultura: o caso da comunidade rural Novo Nilo. Espacios, 2016; 37 (3).

46. Queiroz RS. Caminhos que andam: os rios e a cultura brasileira. In: Rebouças AC, Braga B, Tundisi JG. Águas doces no Brasil: capital ecológico, uso e conservação. 3. ed. São Paulo: Escrituras; 2006.

47. Paes GSM. Os negros d'água do rio Ribeira de Iguape: mito e história numa narrativa elaborada por comunidades negras do Vale do Ribeira. Revista Brasileira de História. 2019;39(81):71-91.

48. Diegues AC. A etnoconservação da natureza. In: Diegues ACD. Etnoconservação: novos rumos para a proteção da natureza nos trópicos. São Paulo: Hucitec e NUPAUB; 2000. p. 1-46.

49. Leite MCS. Meu corpo até arrepia, só de falar! In: Diegues AC, editor. A imagem das águas. São Paulo: Hucitec; 2000. pp. 143-56.

50. Santana R. Poéticas do imaginário popular: serpentes no Quilombo de Mata Cavalo - MT. Cuiabá. Tese [Doutorado em Estudos de Cultura Contemporânea] - Universidade Federal de Mato Grosso; 2018.

51. Lourenço SR, Silva DKP. Uma análise antropológica sobre a cosmologia da comunidade quilombola de Lagoinha de Cima: entre santos, "arrumações" e seres não-humanos. Aceno. 2016;3(6):71-86.

52. Maluf SW. Além do templo e do texto: desafios e dilemas dos estudos de religião no Brasil. Revista Antropologia em primeira mão. 2011;124:5-14.

53. Magalhães HF, Costa Neto EM, Schiavetti A. Cosmovisão e etnoconservação nos manguezais do município de Conde, litoral norte do estado da Bahia. Brasil Etnobiología. 2014;12(1):23-9.

54. Pereira BE, Diegues AC. Conhecimento de populações tradicionais como possibilidade de conservação da natureza: uma reflexão sobre a perspectiva da etnoconservação. Desenvolv e Meio Ambient. 2010.

55. Vieira IR, Oliveira JSO. Santos KPP, Vieira FJ, Barros RFM. Cosmovisión y etnoconservación en morichales (buritizales), estado de Maranhão. Brasil Espacios. 2016;37(24):1-5.

56. Melo MFT, Barros FB. O mundo segundo os quilombolas do bairro alto (llha de Marajó): Cosmovisões acerca da vida e das relações sociedade e natureza. Aceno. 2016;3(6):120-36.

57. Maués RH. A Ilha Encantada: medicina e xamanismo numa comunidade de pescadores. Belém: UFPA; 1990. 
58. Maués RH. Um aspecto da diversidade cultural do caboclo amazônico: a religião. Estudos avançados. 2005;19(53):259-74.

59. Ribeiro CR, Luna JF, Almeida BK. A importância dos mitos para as sociedades indígenas. In: Anais do VII Congresso Internacional de História; 2015 out 6-9; Maringá, PR. Maringá: Ed. Universidade Estadual de Maringá, 2015. p. 1421-1432.

60. Rego FCVS, Silva ARNC. O pensamento social brasileiro em superstição e costumes de Luís da Câmara Cascudo. Imburana. 2012; 6.

\section{Figures}

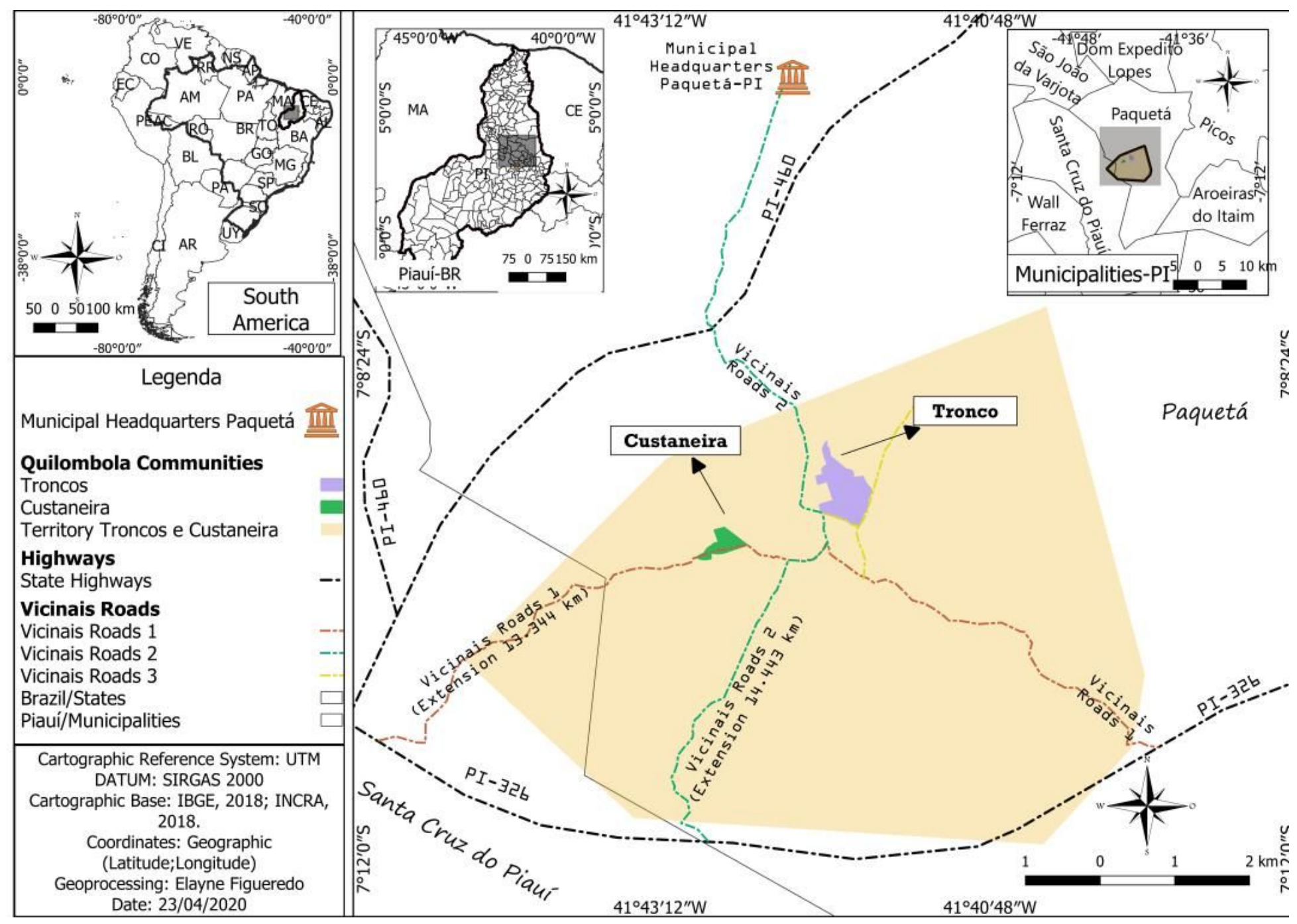

Figure 1

Custaneira/Tronco community location map. Source: [25]. 